研究

\title{
アルミナ射出成形体の脱脂挙動
}

佐々木卓也

住友重機械工業儌平塚研究所, 宁254 平塚市夕陽ヶ 丘63-30.

\section{Debinding Behavior for Injection Molded Alumina Compacts}

Takuya Sasaki

Sumitomo Heavy Industries Ltd., 63-30 Yuhigaoka, Hiratsuka 254.

Received August 18, 1992

A thermal treatment causes occasionally some defects for green body like cracks or $b$ listers in a binder removal stage of the ceramic injection molding process.

A debinding mechanism by heating for the injection molded alumina contained the EVA and Wax is investigated in this study. By means of observations of a cross section of the alumina compact in the heating process, it has been found that the brown layer, formed at the surface, advances into the compact during the process. The non-degraded binder as a white region has been also observed inside of the layer.

The surface layer is postulated as a kind of reactant in the heating process. From the result of the analysis of kinetics for the reaction system, the rate determining step will be proposed for a reaction at the interface between the brown surface layer and the white inner region.

\section{1 緒 言}

粉末射出成形法は，複雑形状品を高精度に作製す ることが可能で, しかも量産性に優れていることか ら, セラミックスや金属粉末等を出発原料とする成 形プロセスのひとつとして注目されている.すでに 自動車用ターボチャージャーローターの製造等, 幅 広い分野へ適用されている゙。このプロセスの最も 特徵的な点は, 多量の有機バインダーを添加して粉 末に流動性を与え，これを成形した後に加熱あるい は抽出などの手段によって脱脂するところにある. 脱脂においては多量のバインダーを効率的に除去す
ることが必要であるが，加熱に伴って割れや膨れな どの欠陷が現れやすいという問題点が従来より指摘 されている2゙.工業プロセスへ適用する場合には， 種々の製品に対してバインダーと脱脂条件を試行錯 䛇と経験によって定めているのが実情であり，指針 となるべき評価基準が見いだしにくいことが，技術 上の大きな課題となっている.これは脱脂現象が， バインダーの蒸発，分解，物質移動など複数の現象 が同時におこる複雑なものであるためと思われるが これを解明することは，工業プロセス上極めて重要 である. 
そこで, 本研究ではアルミナ射出成形体の加熱脱 脂においてバインダーが除去される過程を調べ, さ らに内部気孔が発生する条件を検討した. またバイ ンダーが除去される過程を反応速度論的にとらえて 反応の律速過程の検討を行った.

\section{2 実験方法}

\section{1 試料の作製}

原料粉末として平均粒径 $0.6 \mu \mathrm{m}$ のアルミナ粉 末 (昭和電工(侏AL160SG)を使用した. バインダーは 成形性および脱脂性を考虑すると, 熱可塑性樹脂と 低融点低粘度物質とを混合することが好ましいので 本実験においてはエチレンー酢ビ共重合樹脂（E V A）とパラフィンワックス（W a x ）を使用した. アルミナ粉末とバインダーをTable 1 に示す比率で 組み合わせ, 加圧式ニーダーで $100 \sim 120^{\circ} \mathrm{C}$, 1 時間の混練を行った. 混練物は造粒機を使用して 約 $3 \mathrm{~mm}$ の粒状とした後, 型締力 25 トンのインライ ンスクリュー式射出成形機で $20 \times 30 \times 12 \mathrm{~mm}$ の ブロック状試料を成形した. なお射出成形機のシリ

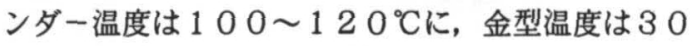
${ }^{\circ} \mathrm{C}$ に設定した.

\section{2 脱脂および脱脂体の評価}

脱脂は熱風循環炉を用いて大気中 $5^{\circ} \mathrm{C} / \mathrm{h}$ の昇温 速度で行い, 試料を脱脂途中で炬から取り出して切 断し内部の観察および切断面のビッカース硬さの測 定を行った. また後述するように, $200^{\circ} \mathrm{C}$ 以上で

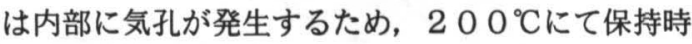
間を $0 \sim 60$ 時間の間で変化させ, それぞれの試料 について深さ方向に $1 \sim 2 \mathrm{~mm}$ 角の小片に切り出して 熱分析を行った.このときの重量変化から試料内部 のバインダー残存量分布を求めた.

Table 1 Compositions of alumina powder and binder mixture (Vol\%)

\begin{tabular}{crcc}
\hline & A & B & C \\
\hline Alumina & 55 & 55 & 55 \\
E V A & 9 & 18 & 27 \\
Wax & 36 & 27 & 18 \\
\hline
\end{tabular}

EVA: Vinyl acetate content $45 \%$

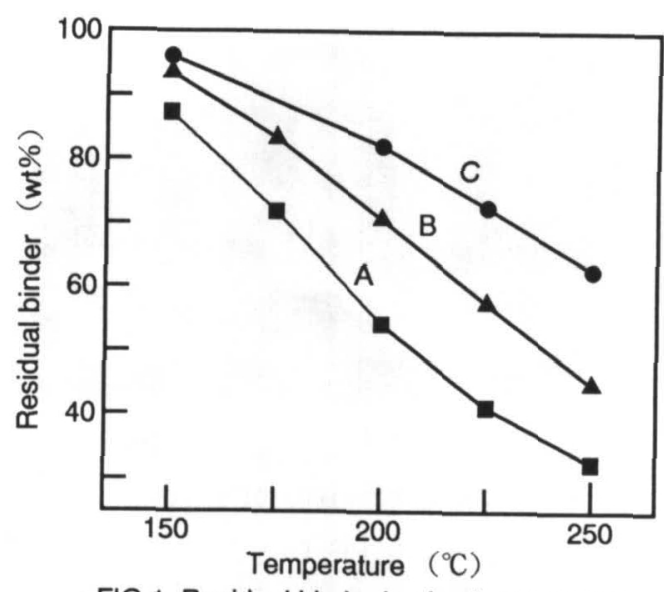

FIG.1 Residual binder in alumina compacts at a heating rate of $5{ }^{\circ} \mathrm{C} / \mathrm{h}$

\section{3 実験結果および考察}

\section{1 脱脂結果}

Fig. 1 はE V A / W a x 比率が異なる試料 A, B

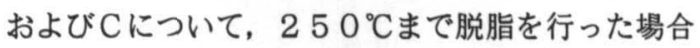
のバインダー残存量である、脱脂はW a x 比率が多 いものほど速やかに進行するが, 試料 A は, 試料 C の約 2 倍の脱脂速度を示し脱脂性は良いと言える. これはW a xがEVAよりも低粘度であり成形体中 の移動が容易なこと, また低温から蒸発, 分解が進 行するためであるが, W a x を多量に含むバインダ 一は射出成形性が劣るため実用上の問題がある. 一

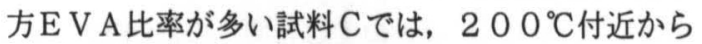
表面が褐色に着色し, 変形あるいは膨れが見られ始

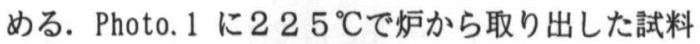
A, B, Cの切断面写真を示すが, 試料 B，Cには 内部に巨大な気孔が発生しており, 表面側から褐色 の層が生成していることが認められた.

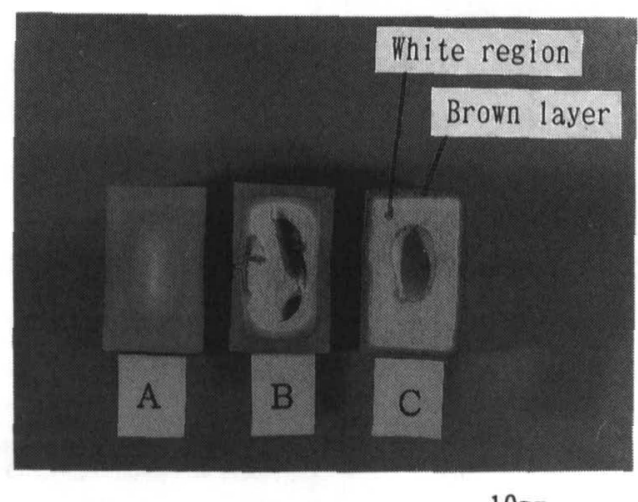

$\underline{10 \mathrm{~mm}}$

Photo. 1 Cross sections of specimen A, B, C heated up to $225 \mathrm{C}$ at a rate of $5 \mathrm{C} / \mathrm{h}$ 


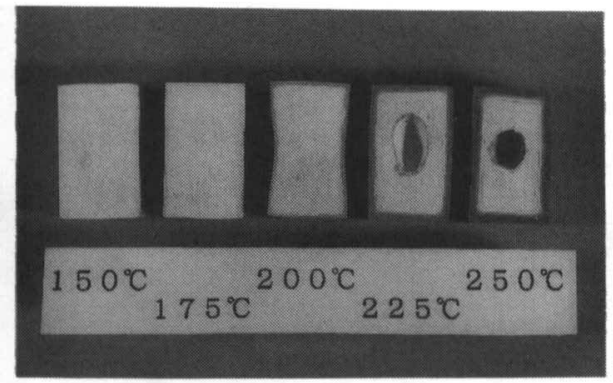

$10 \mathrm{~mm}$

Photo. 2 Cross sections of specimen $\mathrm{C}$ at a heating rate of $5 \mathrm{c} / \mathrm{h}$

Photo. 2 には, 脱脂途中の各温度で取り出した試

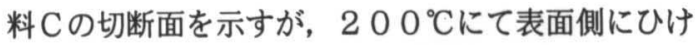
が見られ，200 Cを越えると内部に気孔が発生し 脱脂温度が高くなるに従って表面側から褐色層が内 部へ進行してゆく状況が観察される.

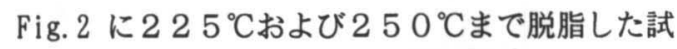
料Cの切断面硬さ分布を示す. 試料内部の白い部分 はH V 10 以下で脱脂前の硬さにほぼ等しいのに対 し, 褐色層の硬さはHV 4 0-50であり試料の表 面側からバインダーが硬化していることがわかる.

Fig. 3 は2 $25^{\circ} \mathrm{C}$ まで脱脂を行った試料Cについて 褐色層と白色部の熱重量分析（TG）を行った結果 である. 白色部の T Gは $380^{\circ} \mathrm{C}$ 付近で減量速度が 低下しており， E V A の T G と同様の傾向を示して

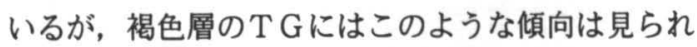

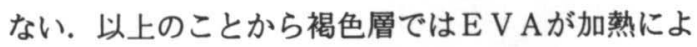
って炭化, 変質しているのに対し, 白色部では $\mathrm{E} \mathrm{V}$ Aがそのままの状態で残存していると推測される.

\section{2 温度保持の効果}

前述の気孔の発生と褐色層の生成には密接な関係 があると考え, 試料 $\mathrm{C}$ を $200^{\circ} \mathrm{C}$ に昇温後, $0-6$ 0 時間保持した. この場合いずれの保持時間でも気 孔は発生せず, 脱脂状態は良好であった. Fig. 4 に バインダー残存量を調べた結果を示す. 図中の黒塗 りの点は褐色層が存在している領域を示しているが 褐色層は60-70\%のバインダー残存量を保ちな がら内部へ進行し, 約 60 時間で中心部へ達してい る. 一方白色部のバインダー残存量は時間とともに 减少してくるが, 白色部内での差は殆どなく, 褐色 層との界面近傍で急激に減少する. 褐色層では, バ インダー残存量が脱脂前のE V A 量にほほ等しいこ

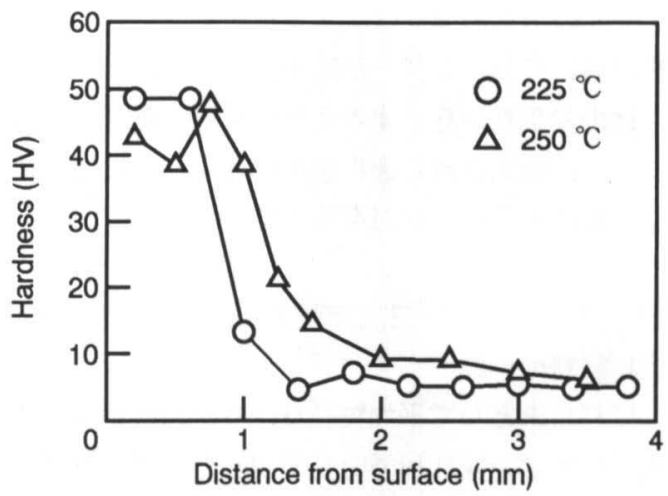

Fig.2 Distribution of hardness for specimen C

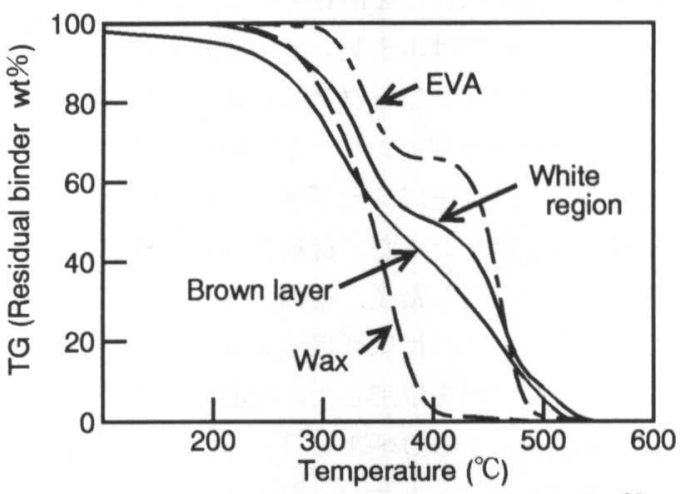

Fig.3 TG analysis for specimen $\mathrm{C}$ heated to $225^{\circ} \mathrm{C}$ and organics

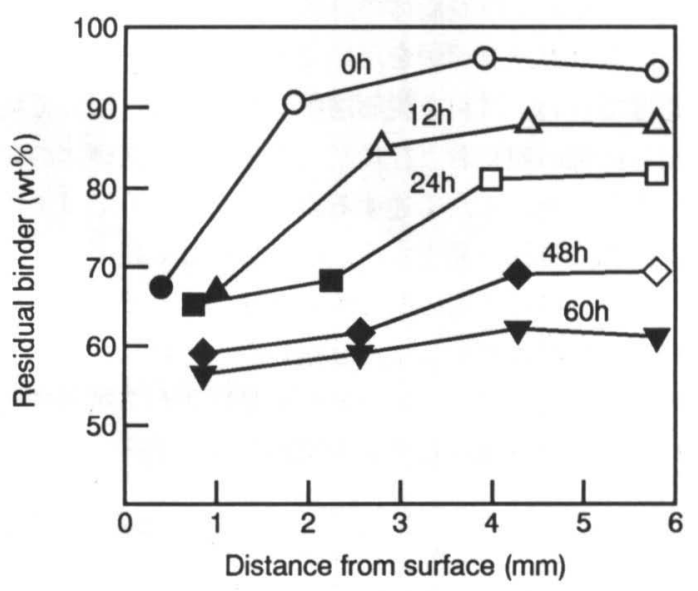

FIG.4 Effect of holding time at $200^{\circ} \mathrm{C}$ on residual binder in alumina compacts

と, また前記 T Gの結果も考えあわせると, W a x 成分が主体に脱脂されているものと思われる.

脱脂において, バインダーが分解し成形体内部か ら外へ抜け出るためには, 分解ガスが透過, 拡散で きるような連続した細孔が必要であり，セラミック ス射出成形体の場合には, $25 \%$ 以上のバインダー 
が除去されていれば可能とされている3!. 本実験に おいて観察されるような白色部の気孔発生機構は, 褐色層が成形体中心部に達しない状態で昇温を続け た結果，バインダーの分解ガスによって成形体内部 のガス圧が上昇し，加熱によって軟化した白色部の 中心に気孔が形成されたものと推測される. したが って，褐色層の存在によりバインダーの分解ガスが 透過可能となり，また試料の形状保持もできたもの と思われる. 以上のことから脱脂途中での成形体内 の褐色層を観察することにより, 脱脂条件決定の判 断基準が容易に得られると考える.

\section{3 褐色層生成過程}

褐色層が生成する過程を, 白色部と褐色層の界面 におけけバインダー（A）と酸素（B）の化学反応 $(A+b$ B $\rightarrow$ 反応物）とする.Fig. 5 に示すような 成形体の断面モデルにて, 反応界面, 成形体表面, 雾团気中のガス濃度を， $\mathrm{C}_{\mathrm{i}}, \mathrm{C}_{\mathrm{s}}, \mathrm{C}_{\mathrm{g}}$ とし図中に示 した直線状の濃度分布を仮定する. 反応系は, 外表 面ガス境膜内拡散, 褐色層内ガス拡散, 界面化学反 応が直列に起こり，いずれかの過程が律速になって いる場合，以下の速度式で表すことができる4).

(1)境膜内払散 $: \mathrm{dx} / \mathrm{d} \theta=-\mathrm{bk}_{\mathrm{g}}\left(\mathrm{C}_{\mathrm{g}}-\mathrm{C}_{\mathrm{s}}\right) / \mathrm{p}$

(2)褐色層内桩散 $: \mathrm{dx} / \mathrm{d} \theta=-\mathrm{bD}\left(\mathrm{C}_{\mathrm{s}}-\mathrm{C}_{\mathrm{i}}\right) /(\mathrm{L}-\mathrm{x})$

(3)界面化学反応 : $\mathrm{dx} / \mathrm{d} \theta=-\mathrm{bk}_{\mathrm{s}} \mathrm{C}_{\mathrm{i}} / \rho$

$\theta$ : 時間, $\rho$ : 未反応部バインダー密度, $D$ : 拡散係数

$\mathrm{k}_{\mathrm{g}}$ : 境膜物質移動係数, $\mathrm{k}_{\mathrm{s}}$ : 反応速度定数 以上の式を積分し, 反応終了時間を $\tau$ として無次元 化して整理したものが，Fig. 6 である. 図中に示し た測定值は, 境膜内拡散あるいは界面化学反応律速 であることを示す直線にのっているが，この反応系 は極めて遅く, 成形体外表面の境膜抵抗は無視し得 るので, 褐色序の生成は界面化学反応律速とみなす ことができる. 以上より, 内部の気孔を発生させず 短時間で脱脂するためには, バインダー添加量を極 力抑える，または䨜囲気中の酸素濃度を上げるなど の方法が有効であることが理論づけられる.

\section{4 ま と}

本実験により, 以下の結果が得られた。

(1) 脱脂昇温中の成形体内部において，表面側から 褐色層が生成進行するのに対し, 内部の白色部はバ

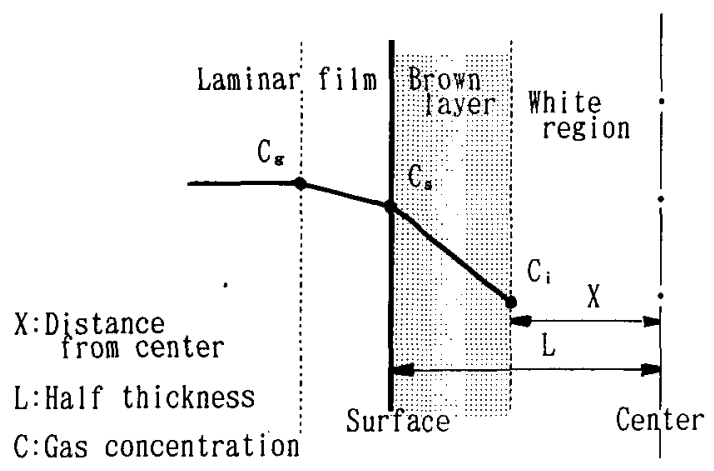

Fig. 5 Infinite plate model of debinding

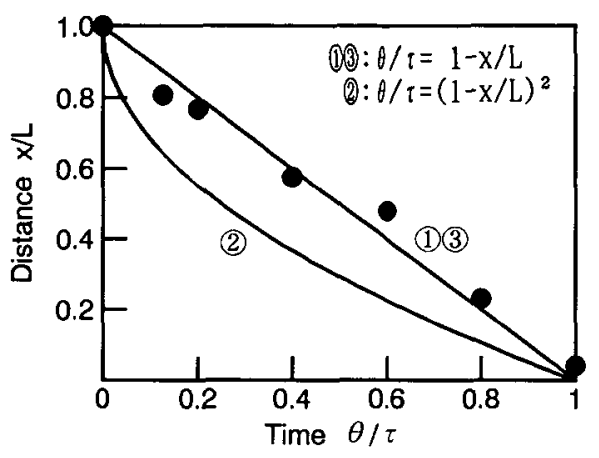

Fig.6 Dependence of the distance of the interface from center on reaction time

インダーが末分解に近い状態で残存しており，気孔 はこの白色部に発生する.

（2）褐色層はバインダーが加熱により炭化したもの と思われるが、バインダー残存量が $70 \%$ 以下であ り, 分解ガスの透過が容易なことから内部気孔発生 防止に寄与している.

（3）褐色層の生成過程は界面化学反応律速であると みなすことができる.

\section{文献}

1)Y.Hattori: Proc. of 2nd International Symp. Ceramic Materials and Components for Engines, (1986) 225.

2) 斎藤勝義, 荒木田豊, 井上誠 : ファインセラミッ クスの射出成形技術，日刊工業新聞社，(1987）

3)S. Wada, Y. Oyama: Proc. of 2nd International Symp. Ceramic Materials and Components for Engines, (1986) 165.

4)化学工学協会編 : 化学工学便覧, 4 版, 丸善 